\title{
Antisense oligonucleotides targeting human telomerase mRNA increases the radiosensitivity of nasopharyngeal carcinoma cells
}

\author{
CHANGE YU*, YING YU*, ZUMIN XU*, HAIWEN LI, DONGYAN YANG, MEI XIANG, \\ YUFANG ZUO, SHUHUI LI, ZIHONG CHEN and ZHONGHUA YU
}

\author{
Cancer Center, Affiliated Hospital of Guangdong Medical College, Zhanjiang, Guangdong 524000, P.R. China
}

Received February 23, 2014; Accepted November 20, 2014

DOI: $10.3892 / \mathrm{mmr} .2014 .3105$

\begin{abstract}
Nasopharyngeal carcinoma (NPC) is associated with a high incidence rate in South China and is predominantly treated with radiotherapy; however, the survival rate remains low. The therapeutic effects of radiation and chemotherapy may be enhanced when combined with anti-sense oligonucleotides targeting human telomerase RNA (hTR ASODN). However, the influence of hTR ASODN on the anti-tumor effects of radiation in NPC remain unknown. The present study investigated the effects of hTR ASODN on the proliferation and radiosensitivity of NPC cells, and further explored the underlying mechanisms. hTR ASODN significantly inhibited the proliferation and decreased the telomere length of CNE-2 human NPC cells. Furthermore, combined treatment of hTR ASODN with radiation significantly enhanced anti-tumor efficacy. The apoptotic rate and cleavage of caspase 9 were increased in the cells treated with the combined therapy, as compared with the cells treated with hTR ASODN or radiotherapy alone. In conclusion, these results suggest that hTR ASODN may inhibit the proliferation of NPC cells and enhance the anti-tumor effects of radiation by inducing cell apoptosis. Therefore hTR ASODN may be a potential adjuvant agent for the treatment of NPC combined with radiation therapy, and these findings are of translational importance.
\end{abstract}

\section{Introduction}

Nasopharyngeal carcinoma (NPC) is a squamous-cell carcinoma derived from the epithelial lining of the nasopharynx (1).

Correspondence to: Professor Zhonghua Yu or Professor Zihong Chen, Cancer Center, Affiliated Hospital of Guangdong Medical College, 57 South Renming Road, Zhanjiang, Guangdong 524000, P.R. China

E-mail: zhonghua_yu@126.com

E-mail: chen.zi.hong@163.com

*Contributed equally

Key words: nasopharyngeal carcinoma, telomerase, anti-sense oligonucleotides, radiosensitivity
Its incidence is rare in the United States and Western Europe, however it is common in endemic areas, including South China, North Africa and Alaska (2). South China has the highest incidence rate of NPC, with 25-30 per 100,000 people affected annually, and it is particularly common among people of Cantonese ancestry (3). Since NPC is sensitive to irradiation, radiotherapy is the main therapeutic strategy used to treat NPC. With the improvement of radiotherapy techniques and chemotherapy, the locoregional control of NPC has improved (4), with a cure rate of $\sim 70 \%$ (5). However, overall survival remains low. Therefore, the development of multidisciplinary therapeutic strategies that improve locoregional control and eradicate micrometastases is required.

Telomeres are repetitive nucleotides that reside at the ends of human chromosomes, and telomere length is mainly maintained through the activity of telomerase (6). Telomerase is activated in $80-95 \%$ of cancers, and is present in very low to undetectable levels in normal cells (7). In normal human cells telomeres are shortened with cell division, however they are continuously elongated in tumor cells. Due to the pivotal role of telomerase in cancer cells, it is considered to be an attractive target for anticancer therapy. Inhibition of telomerase may lead to decreased telomere length, resulting in cell apoptosis in telomerase-positive tumors (8). Potential telomerase inhibitors, including small molecules, antisense oligonucleotides and ribozymes, have previously been developed (9). Preclinical studies have demonstrated that antisense oligonucleotides targeting human telomerase RNA (hTR ASODN) are promising agents for the treatment of various human malignancies (10). In addition, the therapeutic effects of chemotherapy $(11,12)$ and radiation (13) were shown to be enhanced when combined with hTR ASODN. However, the influence of hTR ASODN on the anti-tumor effects of radiation in NPC remain to be elucidated.

The present study aimed to investigate the influence of hTR ASODN on the proliferation and radiosensitivity of NPC cells, and to further explore the underlying mechanisms.

\section{Materials and methods}

Cell culture. CNE-2 human undifferentiated NPC cells were cultured in RPMI-1640 medium (Gibco Life Technologies, Carlsbad, CA, USA) supplemented with $10 \%$ fetal bovine serum (FBS; Gibco Life Technologies) at $37^{\circ} \mathrm{C}$, in a humidified 
incubator containing $5 \% \mathrm{CO}_{2}$. Cells at the logarithmic growth phase were used in the following experiments.

Cell transfection. hTR ASODN was synthesized by Guangzhou Geneseed Biotechnology Co., Ltd. (Guangzhou, China), the sequence of which was: 5'-TAGGGTTAG ACAA-3'. The CNE-2 human NPC cells were transiently transfected with hTR ASODN using Lipofectamine ${ }^{\circledR}$ 2000 Transfection reagent (Invitrogen Life Technologies, Carlsbad, CA, USA). The CNE-2 cells $\left(5 \times 10^{6}\right.$ cells $\left./ \mathrm{ml}\right)$ were transfected with $0.5,1.0,1.5,2.0,2.5$ or $3.0 \mu \mathrm{mol} \mathrm{DNA} / 10^{6}$ cells (Lipofectamine ${ }^{\circledR}:$ DNA, 3:1). The transfection efficiency was evaluated by flow cytometry $24 \mathrm{~h}$ post-transfection. Cells transfected with Lipofectamine ${ }^{\circledR} 2000$ only were used as the control group.

Flow-fluorescent in situ hybridization (FISH) assay. The CNE-2 cells were transfected with control or hTR ASODN $(2.5 \mu \mathrm{mol})$ for $12 \mathrm{~h}$. Irradiation was then conducted at room temperature using an RS 2000 X-ray Biological Irradiator (Rad Source Technologies, Inc., Suwanee, GA, USA), at a dose rate of $1 \mathrm{~Gy} / \mathrm{min}$ through a $0.2 \mathrm{~mm}$ copper filter. The cells were cultured for a further $36 \mathrm{~h}$ in RPMI-1640 medium without $\mathrm{FBS}$ at $37^{\circ} \mathrm{C}$ in a humidified incubator containing $5 \% \mathrm{CO}_{2}$. A total of $1 \times 10^{6}$ cells from each sample were washed in $2 \mathrm{ml}$ phosphate-buffered saline (PBS; $135 \mathrm{mM} \mathrm{NaCl}$, $1.3 \mathrm{mM} \mathrm{KCl}, 3.2 \mathrm{mM} \mathrm{Na}_{2} \mathrm{HPO}_{4}, 0.5 \mathrm{mM} \mathrm{KH} \mathrm{PO}_{4}$ ) supplemented with $0.1 \%$ bovine serum albumin (BSA; Guangzhou Chemistry Reagent Factory, Guangzhou, China). Each sample was divided into two replicate tubes; one pellet was resuspended in $80 \mu \mathrm{l}$ hybridization buffer $(10 \mathrm{mM} \mathrm{NaHPO}$, $\mathrm{pH} 7.4 ; 10 \mathrm{mM} \mathrm{NaCl} ; 20 \mathrm{mM}$ Tris, $\mathrm{pH} \mathrm{7.5;} \mathrm{70 \%} \mathrm{formamide),}$ and another in hybridization buffer without fluorescein isothiocyanate (FITC)-labeled telomeric peptide nucleic acid probe, which was used as a negative control. The samples were then denatured for $15 \mathrm{~min}$ at $87^{\circ} \mathrm{C}$ with continuous agitation and hybridized for $2 \mathrm{~h}$ in the dark at room temperature. The cells were subsequently washed twice in washing solution (70\% deionized formamide, $10 \mathrm{mM}$ Tris, $0.1 \%$ BSA and $0.1 \%$ Tween ${ }^{\circledR} 20$ in distilled $\mathrm{H}_{2} \mathrm{O} ; \mathrm{pH}$ 7.2). The cells were then centrifuged at $956 \mathrm{x}$ g for $10 \mathrm{~min}$, resuspended in $500 \mu \mathrm{l}$ of propidium iodide (PI) solution (Kaiji Biotechnology, Nanjing, China), incubated for $2 \mathrm{~h}$ at room temperature and stored at $4^{\circ} \mathrm{C}$, prior to flow cytometric analysis.

Cell proliferation assay. Cell viability following transfection with hTR ASODN was measured by an MTT assay (Sigma-Aldrich, St. Louis, MO, USA), as described previously (14). Cells in early log phase were trypsinized with $0.25 \%$ trypsin (Gibco Life Technologies, Rockville, MD, USA) and seeded in 96-well plates $\left(2 \times 10^{3}\right.$ cells/well). Following a $36 \mathrm{~h}$ incubation in RPMI-1640 medium with $10 \%$ fetal bovine serum at $37^{\circ} \mathrm{C}$, the medium was refreshed. Cell density was measured using MTT, according to the manufacturer's instructions. The absorbance of the converted dye was measured at a wavelength of $450 \mathrm{~nm}$ using a plate reader (Multiskan MK3; Thermo Labsystems, Waltham, MA, USA), and the absorbance was considered directly proportional to cell viability. This experiment was repeated $\geq$ three times.
Colony formation assay. The clonogenic potential of the cells treated with hTR ASODN and/or ionizing radiation was assessed using a colony formation assay. Briefly, the cells were transfected with the control or hTR ASODN $(2.5 \mu \mathrm{mol})$ for $12 \mathrm{~h}$. Cells were trypsinized and plated in six-well plates at 200, 500,3,000,5,000, and 10,000 cells per well and cultured overnight to allow for cell attachment. Irradiation was then performed at room temperature using an RS 2000 X-ray Biological Irradiator, at doses corresponding to 0, 2, 4, 6, and $8 \mathrm{~Gy}$, through a $0.2 \mathrm{~mm}$ copper filter. The plates were then incubated for 10 days at $37^{\circ} \mathrm{C}$, and the growth medium was replaced every three days. The plates were then stained with $0.1 \%$ crystal violet (Sigma-Aldrich), and colonies containing $\geq 50$ cells were counted under an inverted microscope (IMT-2; Olympus Corp., Tokyo, Japan). The cell surviving fraction was determined relative to the survival of non-irradiated cells transfected with Lipofectamine ${ }^{\circledR} 2000$ only.

Apoptosis assay. The percentage of apoptotic cells was determined by flow cytometry using the Annexin V-FITC Apoptosis Detection kit (Kaiji Biotechnology Co., Nanjing, China), as described previously (14). Briefly, the cells were collected, washed three times with PBS and fixed with $1 \mathrm{ml}$ ethanol (70\%) for $2 \mathrm{~h}$ at $4^{\circ} \mathrm{C}$. The cells were washed again with PBS, and the supernatants were removed following centrifugation at $956 \mathrm{x} \mathrm{g}$ for $10 \mathrm{~min}$. The cells were then treated with $500 \mu \mathrm{l}$ Annexin binding buffer, $5 \mu \mathrm{l}$ Annexin V-FITC and $5 \mu \mathrm{l} \mathrm{PI}$, and incubated at room temperature in the dark for $15 \mathrm{~min}$. The rate of cell apoptosis was determined by flow cytometry (BD Biosciences, Franklin Lakes, NJ, USA).

Western blot analysis. The CNE-2 cells were transfected with the control or hTR ASODN $(2.5 \mu \mathrm{mol})$ and/or radiation at a total dose of 6 Gy $12 \mathrm{~h}$ post-transfection. At $36 \mathrm{~h}$ post-transfection, whole cell lysates were collected and protein concentrations were determined using the Bio-Rad Protein Assay kit (Bio-Rad Laboratories, Inc., Hercules, CA, USA). Whole cell extracts were separated using 14\% SDS-PAGE and transferred onto PVDF membranes (Bio-Rad Laboratories, Inc.). Following incubation with 5\% nonfat milk in TBST (10 mM Tris, pH 8.0, $150 \mathrm{mM} \mathrm{NaCl,} \mathrm{0.5 \%} \mathrm{Tween}$ 20) for $1 \mathrm{~h}$, the membranes were washed once with TBST and incubated with a polyclonal rabbit anti-Caspase 9 antibody (9502; 1:1,000; Cell signaling technology, Inc., Danvers, MA, USA) at $4^{\circ} \mathrm{C}$ overnight. Membranes were then washed three times with TBST for $10 \mathrm{~min}$ and incubated with horseradish peroxidase-conjugated anti-rabbit antibodies (1:2,000; A0208; Beyotime Institute of Biotechnology, Shanghai, China) at $4^{\circ} \mathrm{C}$ for $2 \mathrm{~h}$. Blots were washed with TBST three times and visualized using Super Enhanced Chemiluminescence Plus Detection Reagent (Applygen Technologies, Inc., Beijing, China) according manufacturer's instructions. The same membrane was stripped and re-blotted with an anti- $\beta$-actin antibody (Sigma-Aldrich) for normalization.

Statistical analysis. Statistical analyses were performed using SPSS version 17.0 software (SPSS, Inc., Chicago, IL, USA). The data are expressed as the mean \pm standard deviation and statistical significance was analyzed by analysis of variance. $\mathrm{P}<0.05$ was considered to indicate a statistically significant difference. 
A

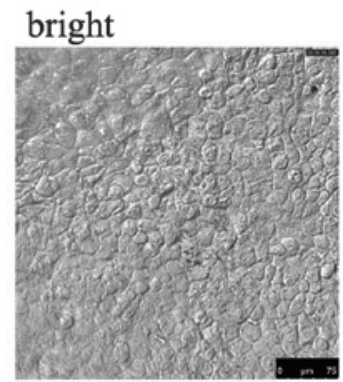

fluorescent

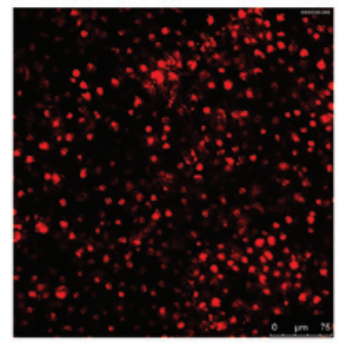

merge

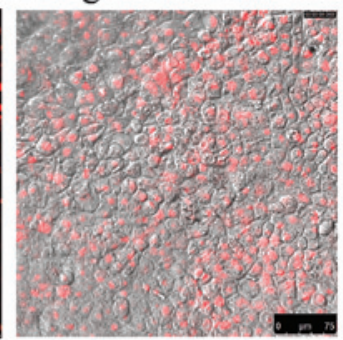

B

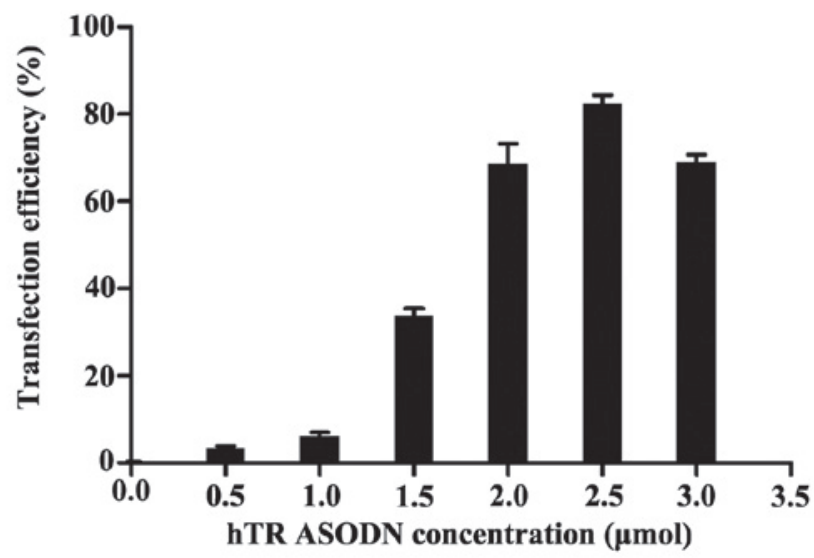

Figure 1. Transfection of antisense oligonucleotides targeting human telomerase RNA (hTR ASODN) into CNE-2 human nasopharyngeal carcinoma cells. CNE-2 cells were transfected with hTR ASODN using Lipofectamine ${ }^{\circledast} 2000$ reagent at various concentrations, as indicated. (A) At $12 \mathrm{~h}$ post-transfection, transfection efficacy was evaluated by detecting the fluorescent intensity using fluorescence correlation microscopy. The images represent the hTR ASODN fluorescence from the transfected cells. (B) Transfection efficiency of the various concentrations of DNA were $2.6 \pm 0.43 \%, 5.2 \pm 0.79 \%, 35.4 \pm 0.51 \%, 69 \pm 0.57 \%$, $82.6 \pm 0.42 \%$ and $69.2 \pm 0.49 \%$, when transfected with $0.5,1.0,1.5,2.0,2.5$ and $3.0 \mu \mathrm{mol}$ DNA, respectively. The best transfection efficiency was observed with a DNA concentration of $2.5 \mu \mathrm{mol} \mathrm{DNA} / 5 \times 10^{6}$ cells, $48 \mathrm{~h}$ post-transfection.

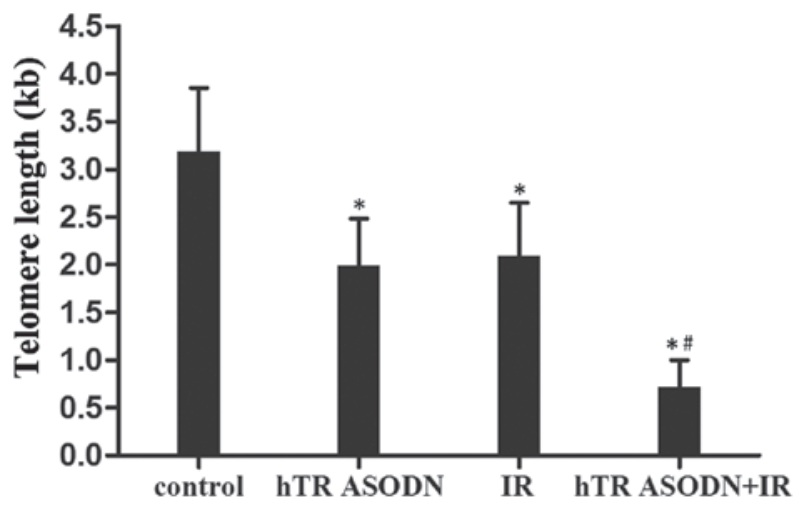

Figure 2. Transfection with antisense oligonucleotides targeting human telomerase RNA (hTR ASODN) in combination with irradiation (IR) decreased the telomere length of CNE-2 human nasopharyneal carcinoma cells. Flow-fluorescent in situ hybridization was used to determine the effects of hTR ASODN and IR on telomere length in CNE-2 cells. Telomere length of the untreated control cells and those treated with IR, hTR ASODN and hTR ASODN combined with IR were $3193 \pm 659$ bases, $2093 \pm 555$ bases, $1993 \pm 491$ bases and $717 \pm 284$ bases, respectively. Data are presented as the mean telomere length values \pm standard deviation. ${ }^{~} \mathrm{P}<0.05$, compared with the control; " $\mathrm{P}<0.05$ compared with the IR or hTR ASODN groups.

\section{Results}

Transient transfection of hTR ASODN into CNE-2 cells. To evaluate the efficacy of hTR ASODN transfection by
Lipofectamine ${ }^{\circledR} 2000$, transfections using various concentrations of DNA were performed. The CNE- 2 cells $\left(5 \times 10^{6}\right.$ cells $\left./ \mathrm{ml}\right)$ were transfected with $0.5,1.0,1.5,2.0,2.5$ or $3.0 \mu \mathrm{mol}$ hTR ASODN (Lipofectamine ${ }^{\circledR}:$ DNA, 3:1). The transfection efficiency of the various concentrations of DNA were 2.6 $\pm 0.43,5.2 \pm 0.79$, $35.4 \pm 0.51,69 \pm 0.57,82.6 \pm 0.42$ and $69.2 \pm 0.49 \%$ when transfected with $0.5,1.0,1.5,2.0,2.5$ and $3.0 \mu \mathrm{mol}$ DNA, respectively. The best transfection efficiency was observed with a DNA concentration of $2.5 \mu \mathrm{mol} \mathrm{DNA} / 5 \times 10^{6}$ cells, $48 \mathrm{~h}$ post-transfection (Fig. 1).

Transfection with hTR ASODN decreases telomere length in CNE-2 cells. Flow-FISH techniques were used to determine the effects of hTR ASODN and radiation on telomere length in CNE-2 cells. The telomere length of the untreated control cells and those treated with irradiation, hTR ASODN and hTR ASODN combined with irradiation were $3193 \pm 659$ bases, $2093 \pm 555$ bases, $1993 \pm 491$ bases and $717 \pm 284$ bases, respectively. In addition, combined treatment with hTR ASODN and irradiation led to an increased rate of apoptosis of the CNE-2 cells (Fig. 2).

hTR ASODN inhibits the growth of CNE-2 cells. To determine the inhibitory effects of hTR ASODN on human NPC cells, the growth of CNE-2 cells was measured using an MTT assay. The CNE-2 cells were transfected with 0.5, 1.0, 1.5, 2.0, 2.5 or $3.0 \mu \mathrm{mol} \mathrm{DNA} / 5 \times 10^{6}$ cells (Lipofectamine ${ }^{\circledR}:$ DNA, $3: 1$ ). 


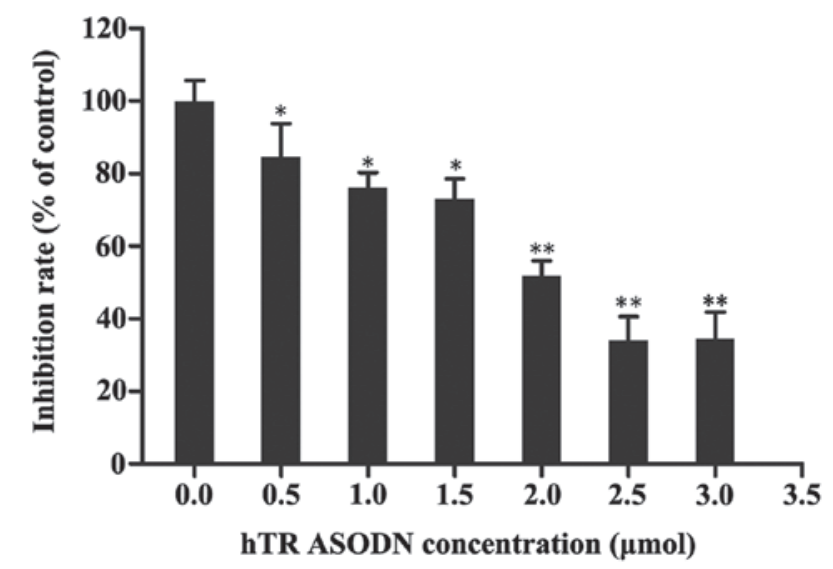

Figure 3. Transfection with antisense oligonucleotides targeting human telomerase RNA (hTR ASODN) inhibited the growth of CNE-2 human nasopharyngeal carcinoma cells. Cell viability was assessed by MTT assay. Cells were transfected with control vectors or hTR ASODN at various concentrations, as indicated, for $24 \mathrm{~h}$. The growth of CNE-2 cells was markedly inhibited $48 \mathrm{~h}$ post-transfection, as compared with the control cells. Data are presented as the mean \pm standard deviation from three independent experiments. ${ }^{*} \mathrm{P}<0.05$ and ${ }^{* *} \mathrm{P}<0.01$ compared with the control cells.

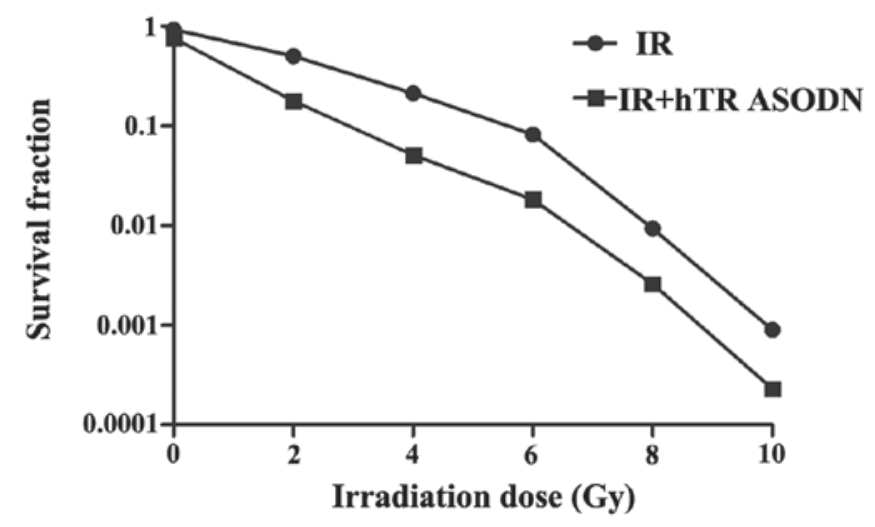

Figure 4. Radiosensitization of CNE-2 human nasopharyngeal carcinoma cells by transfection with antisense oligonucleotides targeting human telomerase RNA (hTR ASODN). CNE-2 cells were transfected with control or hTR ASODN for $24 \mathrm{~h}$ prior to irradiation (IR). Cells transfected with hTR ASODN $(2.5 \mu \mathrm{mol})$ followed by IR exhibited a greater inhibition of colony formation, as compared with the control $(\mathrm{P}<0.01)$. The clonogenic survival fraction revealed that the sensitization enhancement ratio was 1.479 . Data points are the averages of two independent experiments, each plated in triplicate.

The growth of CNE-2 cells was markedly inhibited $48 \mathrm{~h}$ post-transfection, as compared with the control cells. The growth inhibitory rate of the cells transfected with hTR ASODN $(2.5 \mu \mathrm{mol})$ was $73 \pm 0.69 \%$ (Fig. 3). These results suggest that hTR ASODN exhibits potential cytotoxic activity against human NPC cells.

hTR ASODN enhances the cytotoxic effects of X-ray irradiation on CNE-2 cells. To determine the effects of hTR ASODN on radiosensitization of CNE-2 cells, a colony forming assay was performed on the cells either treated with irradiation, or transfected with hTR ASODN $(2.5 \mu \mathrm{mol})$ followed by irradiation. The cells transfected with hTR ASODN followed by radiation exposure exhibited a greater inhibition of colony formation, as compared with the control cells (Fig. 4, P<0.01).
Further analysis of clonogenic survival indicated that the sensitization enhancement ratio (SER) was 1.479. These results suggest that hTR ASODN may be capable of sensitizing NPC cells to the cytotoxic effects of radiation treatment.

hTR ASODN enhances the pro-apoptotic effects of X-ray irradiation in CNE-2 cells. To investigate the underlying mechanisms of the inhibition of colony survival following transfection of the CNE-2 cells with hTR ASODN $(2.5 \mu \mathrm{mol})$ and radiation ( $6 \mathrm{~Gy}$ ), the cells were analyzed by flow cytometry. The rate of apoptosis was significantly increased by transfection with hTR ASODN or irradiation alone, as compared with the control group. Combined treatment of hTR ASODN with irradiation significantly increased the rate of cell apoptosis, as compared with either hTR ASODN or irradiation treatment alone (Fig. 5A). The apoptotic rate of the untreated controls and the cells treated with irradiation, hTR ASODN and hTR ASODN combined with irradiation were $3.2 \pm 0.6,9 \pm 2.2$, $14.2 \pm 2.1$ and $23.8 \pm 1.87 \%$, respectively. Combined treatment of hTR ASODN with irradiation led to increased cell apoptosis of $\mathrm{CNE}-2$ cells (Fig. 5B, $\mathrm{P}<0.05$ ). In addition, the results of a western blot analysis suggested that combined treatment of hTR ASODN with irradiation led to increased protein expression levels of cleaved caspase 9 in the CNE- 2 cells, thus indicating an increased rate of cell apoptosis (Fig. 6).

\section{Discussion}

The present study explored the effects of hTR ASODN on the CNE-2 NPC cell line. Transfection with hTR ASODN significantly reduced the telomere length, inhibited the proliferation of NPC cells and enhanced the anti-tumor efficacy of radiation by inducing cell apoptosis. This is the first study, to the best of our knowledge, to determine the effects of hTR ASODN in combination with radiation on NPC.

The results of the present study demonstrated that hTR ASODN was efficiently transfected into CNE-2 cells using Lipofectamine ${ }^{\circledR}$ 2000. The transfection efficiency reached $82.6 \%$ when the cells were transfected with $2.5 \mu \mathrm{mol}$ DNA $/ 5 \times 10^{6}$ cells. Furthermore, transfection with hTR ASODN significantly reduced the growth of the CNE-2 cells. Human telomerase consists of the hTR and the human reverse transcriptase catalytic subunit (hTERT) (15). Since telomerase activity is present in $\sim 90 \%$ of human cancer cells, but not in the majority of normal human somatic cells, telomerase inhibition is considered to be a potent molecular target in cancer therapeutics (16). A previous study detected frequently increased levels of telomerase activity in NPC, as compared with normal nasopharyngeal tissue (17). Furthermore, previous studies have observed tumor inhibitory effects by targeting telomerase. Wang et al (18) demonstrated that short hairpin RNA targeting hTERT inhibited cell viability in NPC cells. In addition, ASODN targeting telomerase were also shown to inhibit the growth of NPC cells (19). Therefore, inhibition of telomerase activity by hTR ASODN may be a potential therapeutic strategy in NPC.

Since radiotherapy is currently the main treatment for NPC, the present study investigated the combined effects of radiation and hTR ASODN on CNE-2 cells. The results demonstrated that transfection with hTR ASODN significantly enhanced the 
A
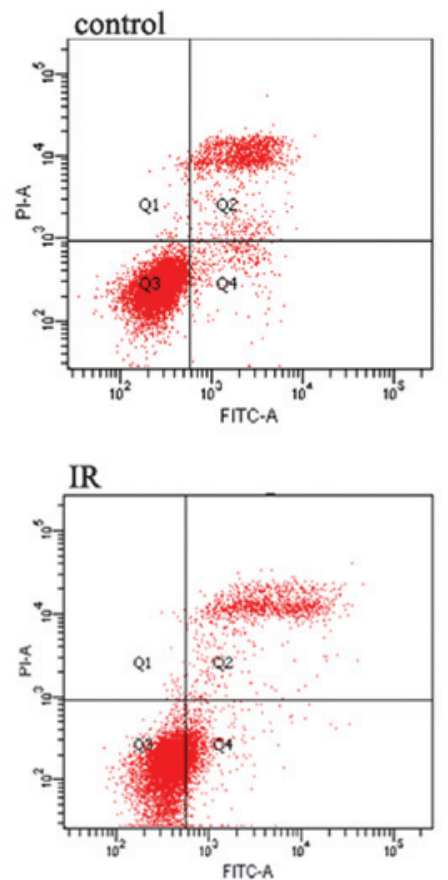

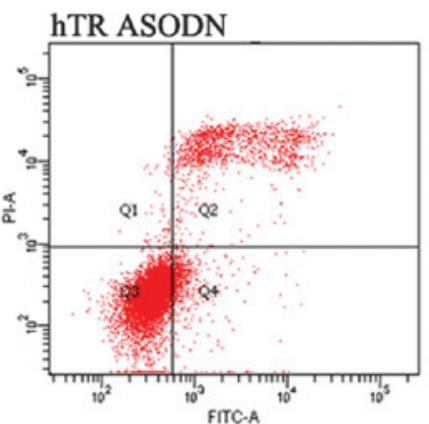

hTR ASODN+IR

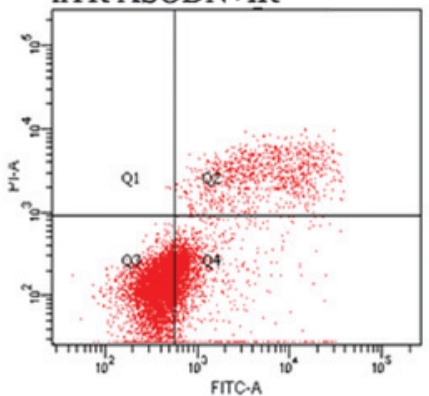

B

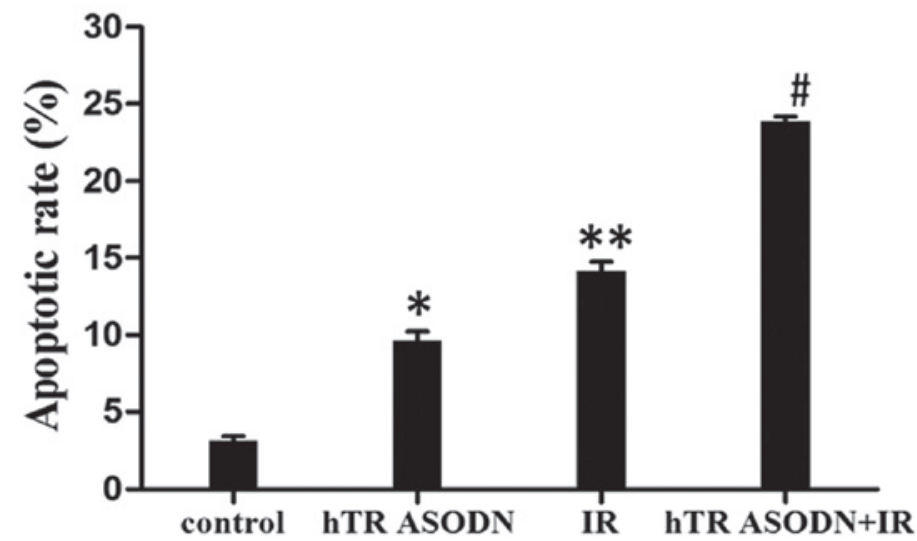

Figure 5. Transfection with antisense oligonucleotides targeting human telomerase RNA (hTR ASODN) combined with irradiation (IR) enhanced the rate of apoptosis of CNE-2 human nasopharyngeal carcinoma cells. The cells were transfected with control or hTR ASODN $(2.5 \mu \mathrm{mol})$ for $24 \mathrm{~h}$, and then irradiated at $6 \mathrm{~Gy}$. (A) Representative images of flow cytometric analysis of the various treatments. (B) Apoptotic rate of cells treated with control, IR, hTR ASODN and hTR ASODN combined with IR was $3.2 \pm 0.6 \%, 9 \pm 2.2 \%, 14.2 \pm 2.1 \%$ and $23.8 \pm 1.87 \%$, respectively. ${ }^{*} \mathrm{P}<0.05$ and ${ }^{* *} \mathrm{P}<0.01$ compared with the control cells; ${ }^{\#} \mathrm{P}<0.05$ compared with the IR or hTR ASODN groups.

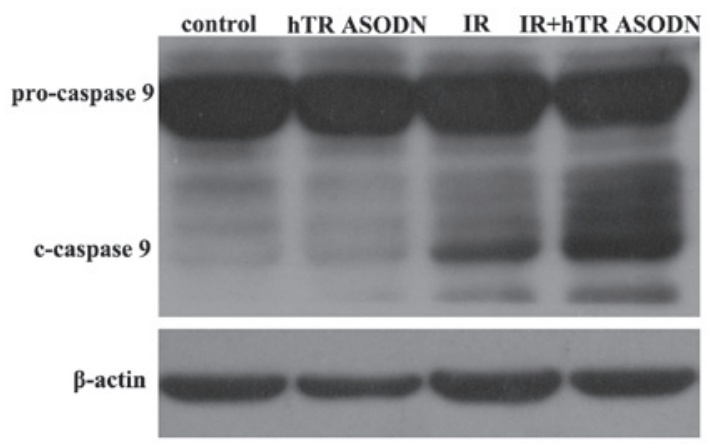

Figure 6. Transfection with antisense oligonucleotides targeting human telomerase RNA (hTR ASODN) combined with irradiation (IR) enhanced the cleavage of caspase 9. CNE-2 human nasopharyngeal carcinoma cells were transfected with control or hTR ASODN $(2.5 \mu \mathrm{mol})$ alone or with $6 \mathrm{~Gy}$ of IR $12 \mathrm{~h}$ post-transfection. Whole cell lysates were collected $24 \mathrm{~h}$ after IR and cleaved caspase 9 (c-caspase 9) protein expression levels were analysed by western blotting. hTR ASODN plus IR significantly increased the cleavage of caspase 9 . radiosensitivity of CNE-2 cells, with a SER of 1.479 . These results were concordant with the findings of previous studies. The shortening of telomeres induced by GRN163L, an oligonucleotide targeting the RNA component of telomerase, was previously shown to significantly enhance the effects of radiation in breast cancer cells (13). Treatment with GRN163L in combination with radiation and temozolomide also exhibited a marked effect on cell survival, and activated the DNA damage response pathway (20). Notably, a previous study demonstrated that high doses of radiation $(2,4$ and $8 \mathrm{~Gy})$ resulted in decreased telomerase activity (down to $30 \%$ of untreated controls), which subsequently resulted in increased cell death, thus suggesting that inhibition of telomerase activity by high doses of radiation may have a role in radiation-induced cell death (21). The present study determined the rate of apoptosis of the untreated cells and those treated with irradiation, hTR ASODN and hTR ASODN combined with irradiation, and 
the rates were $3.2 \pm 0.6,9 \pm 2.2,14.2 \pm 2.1,23.8 \pm 1.87 \%$, respectively. These results suggest that transfection with hTR ASODN combined with irradiation significantly increased the rate of cell apoptosis, as compared with either hTR ASODN or irradiation treatment alone. In addition, the results of a western blot analysis demonstrated that transfection with hTR ASODN combined with irradiation significantly increased the protein expression levels of cleaved caspase 9. Therefore, it may be hypothesized that hTR ASODN combined with radiation may induce cell apoptosis by synergistically reducing telomerase activity.

In conclusion, the present study demonstrated that hTR ASODN could inhibit the proliferation of NPC cells and enhance the anti-tumor effects of radiation by inducing cell apoptosis. These data indicate that hTR ASODN may be a potential adjuvant agent for the treatment of NPC in combination with radiation therapy, and this finding is of translational importance.

\section{Acknowledgements}

The present study was supported by the National Nature Science Foundation of China (grant no. 81201736), the Science and Technology Planning Project of Guangdong Province, China (grant nos. KZ 0710, KZ 1021 and 2007B031516001) and the Science and Technology Innovation Project of Guangdong Medical College, China (grant no. TD1124).

\section{References}

1. Wei WI and Sham JS: Nasopharyngeal carcinoma. Lancet 365: 2041-2054, 2005.

2. Yu MC and Yuan JM: Epidemiology of nasopharyngeal carcinoma. Semin Cancer Biol 12: 421-429, 2002.

3. Feng BJ, Huang W, Shugart YY, et al: Genome-wide scan for familial nasopharyngeal carcinoma reveals evidence of linkage to chromosome 4. Nat Genet 31: 395-399, 2002.

4. Lee N, Xia P, Quivey JM, et al: Intensity-modulated radiotherapy in the treatment of nasopharyngeal carcinoma: an update of the UCSF experience. Int J Radiat Oncol Biol Phys 53: 12-22, 2002.

5. Yang GD, Huang TJ, Peng LX, et al: Epstein-Barr Virus_Encoded LMP1 upregulates microRNA-21 to promote the resistance of nasopharyngeal carcinoma cells to cisplatin-induced Apoptosis by suppressing PDCD4 and Fas-L. PLoS One 8: e78355, 2013.
6. Ruden M and Puri N: Novel anticancer therapeutics targeting telomerase. Cancer Treat Rev 39: 444-456, 2013.

7. Ouellette MM, Wright WE and Shay JW: Targeting telomerase-expressing cancer cells. J Cell Mol Med 15: 1433-1442, 2011.

8. Ruden M and Puri N: Novel anticancer therapeutics targeting telomerase. Cancer Treat Rev 39: 444-456, 2013.

9. Röth A, Harley CB and Baerlocher GM: Imetelstat (GRN163L) - telomerase-based cancer therapy. Recent Results Cancer Res 184: 221-234, 2010.

10. Shay JW and Keith WN: Targeting telomerase for cancer therapeutics. Br J Cancer 98: 677-683, 2008.

11. Xu Q, Zhang Z, Zhang P and Chen W: Antisense oligonucleotides and all-trans retinoic acid have a synergistic anti-tumor effect on oral squamous cell carcinoma. BMC Cancer 8: 159, 2008.

12. Goldblatt EM, Gentry ER, Fox MJ, Gryaznov SM, Shen C and Herbert BS: The telomerase template antagonist GRN163L alters MDA-MB-231 breast cancer cell morphology, inhibits growth, and augments the effects of paclitaxel. Mol Cancer Ther 8: 2027-2035, 2009.

13. Gomez-Millan J, Goldblatt EM, Gryaznov SM, Mendonca MS and Herbert BS: Specific telomere dysfunction induced by GRN163L increases radiation sensitivity in breast cancer cells. Int J Radiat Oncol Biol Phys 67: 897-905, 2007.

14. Xu Z, Fang S, Zuo Y, et al: Combination of pigment epithelium-derived factor with radiotherapy enhances the antitumor effects on nasopharyngeal carcinoma by downregulating vascular endothelial growth factor expression and angiogenesis. Cancer Sci 102: 1789-1798, 2011.

15. Blackburn EH: Switching and signaling at the telomere. Cell 106: 661-673, 2001.

16. Kyo S and Inoue M: Complex regulatory mechanisms of telomerase activity in normal and cancer cells: how can we apply them for cancer therapy? Oncogene 21: 688-697, 2002.

17. Zhang $\mathrm{Y}$, Zhang $\mathrm{H}$, Zhai $\mathrm{Y}$, et al: A functional tandem-repeats polymorphism in the downstream of TERT is associated with the risk of nasopharyngeal carcinoma in Chinese population. BMC Med 9: 106, 2011.

18. Wang Y, Duan HG, Chen SM, Xiao BK, Cheng J and Tao ZZ: Effect of RNA interference targeting human telomerase reverse transcriptase on telomerase and its related protein expression in nasopharyngeal carcinoma cells. J Laryngol Otol 121: 476-482, 2007.

19. Zhang SZ, Huang PC, Xu Y, Chen J and Cai KR: Effects of telomerase sense and antisense oligodeoxynucleotides on growth and differentiation of nasopharyngeal carcinoma cells. Ai Zheng 21: 493-497, 2002 (In Chinese).

20. Marian CO, Cho SK, McEllin BM, et al: The telomerase antagonist, imetelstat, efficiently targets glioblastoma tumor-initiating cells leading to decreased proliferation and tumor growth. Clin Cancer Res 16: 154-163, 2010.

21. Wang X, Liu Y, Chow LS, et al: Regulation of telomerase activity by gamma-radiation in nasopharyngeal carcinoma cells. Anticancer Res 20: 433-437, 2000. 